\title{
Globalization: The Paradox of Political Governance in Kenya: Domestic, Global, and Historical Forces
}

\author{
Meshack Mairura Sagini \\ Langston University, Langston, USA

\begin{abstract}
This essay is an historical, global, and intellectually oriented analytical commentary on 2013 general and quinquennial presidential election in Kenya and the factors that contributed to its outcome. The analysis and its interpretive conclusion have been informed via the reading of professor Sagini’s two books.
\end{abstract} \\ Keywords: elections, politics, paradox, history, Kenya
}

\section{Introduction}

During the week of March 4th 2013, eight candidates competed for the presidency of the Republic of Kenya. Uhuru Kenyatta is the leader of the jubilee coalition and Raila Odinga is the leader of ODM/CORD coalition party. While Kenyatta received $50.07 \%$ of the electorate vote, Odinga got $43.28 \%$. Of the 12.3 million votes cast, 14.3 million were eligible to vote; that is $86 \%$ voter turnout which was very high indeed. The other six candidates were evidently unelectable. In addition, 290 members of parliament, 100 senators, 47 county representatives for women, 47 governors and local councellors were elected. This federal devolution of structural power was popularly agreed on in 2010 when the First Federal Constitution of the Second Republic was bargained and ratified. Devolution is the downward constitutional or cultural handing and passing of power from a higher authority i.e., (from central to provincial/county) governments. This transfer of power is a devolutionary activity whose processes culminate in the sharing of responsibility for governance. In Kenya, since the responsibility to govern devolved upon the counties, the latter have legally and morally acquired power for exercising their sovereignty hence federalism. The constitution divided and limited power within the executive, legislative, and judicial branches of government. It instituted the principles of separation of powers, independence of the judiciary, and an adversarial relationship between the president and parliament for the purpose of preventing tyranny. The constitution also delegated power to the national (federal government) and reserved power for states in order to ensure that if one system abuses the people, the other will protect them and their rights as well. This model of popular and administrative governance is not only American in sentiment, but at best, it is the profound Kenyanization of Montesquieuism. Montesquieu's thinking was influenced by his Esprit des lois (1748) i.e., The Spirit of Laws.

The Spirit of Laws is a treatise on political theory that was first published anonymously by Charles de Secondat, Baron de Montesquieu in 1748 with the help of Claudine Guérin de Tencin. Originally, it was

Meshack Mairura Sagini, Ph.D., Professor of History of Education \& Political Science, Langston University. 
published anonymously partly because Montesquieu's works were continuously subjected to scrutiny. Also, the influence of these works, outside of France, was aided by its rapid translation into many languages. Yet, Montesquieu's political treatise had an enormous influence on the work of many others, most notably: Catherine the Great, who produced Nakaz (Instruction). The Spirit of the Laws inspired Catherine II of Russia to overthrow her inept husband, Peter III for his despotism. She reformed local government administration in 1775. She recognized the nobility and gave them privileges enshrined in a new charter(constitution) in 1785 . She expanded Russian territory, became a writer of memoirs and plays and a patron of intellectuals. Second, this document inspired the Founding Fathers of the United States Constitution particularly Thomas Jefferson, James Madison, Benjamin Franklin, and Alexis de Tocqueville of France who applied Montesquieu's methods to the study of American society, in Democracy in America. Montesquieu spent around twenty one years researching and writing $L$ 'esprit des lois (The Spirit of the Laws), covering many things like the law, social life, and the study of anthropology and provided more than 3,000 commendations. In this political treatise, Montesquieu advocated a democratic (republican) constitutional system of government and the separation of powers, the ending of slavery, the preservation of civil liberties and the law, and the idea that political institutions should reflect the social and geographical aspects of each community. In a republican system of government, monarchical traditions are not allowed to exist. The people rule because they elect rulers to represent them in parliament. The system practices political equality for the protection of liberty, justice, rule of law and democracy.

\section{Constitutional Theory}

In his hierarchy of classification of kinds of political systems, Montesquieu rationalized three main kinds: republican, monarchical, and despotic. Republican political systems vary depending on how broadly they extend citizenship rights.Those that extend citizenship relatively broadly are termed democratic republics, while those that restrict citizenship more narrowly are termed aristocratic republics. The distinction between monarchy and despotism hinges on whether or not "intermediate powers" (such as the nobility, the clergy, etc.) exist and can restrain the authority of the ruler. If it exists, the regime counts as a monarchy; if not, it counts as a despotism. Despotic political institutions are tyrannically dictatorial and undemocratic.

\section{Principles That Motivate Citizen Behavior According to Montesquieu}

Driving each classification of political system, according to Montesquieu, must be what he calls a "principle”. This principle acts as a spring or motor to motivate behavior on the part of the citizens in ways that will tend to support that regime and make it function in three major ways:

(1) For democratic republics (and to a somewhat lesser extent for aristocratic republics), this Rousseauvian spring is the love of virtue - the willingness to put the interests of the community ahead of private interest.

(2) For monarchies, the spring is the love of honor - the desire to attain greater rank and privilege in society.

(3) Finally, for despotisms, the spring is the fear of the ruler. In other words, for each system of government, the motor that motivates behavior is the reason for its existence. If that motor is changed the specific system will cease to be. Most third world leaders love to wallor in the last two springs and as a result are unstable most of the time.

Parenthetically, a political system cannot last long if its appropriate principle is lacking. Montesquieu claims, 
for example, that the English failed to establish a republic after the Civil War (1642-1651) because the society lacked the requisite for love of virtue.

A second major theme in De l'esprit des lois concerns political liberty and the best means of preserving it. "Political liberty" is Montesquieu's concept of what we might call today personal security, especially insofar as this provided for a system of dependable and moderate laws. He distinguishes this view of liberty from two other, misleading views of political liberty. The first is the view that liberty consists in collective self-government, i.e., that liberty and democracy are the same. The second is the view that liberty consists in being able to do whatever one wants without constraint. Not only are these latter two not genuine political liberty, he thinks, they can both be hostile and destructive to it.

Political liberty is not possible in a despotic political system, but it is possible, though not guaranteed, in republics and monarchies. Generally speaking, establishing political liberty on a sound footing requires two things:

The first is the separation of the powers of government.

Building on and revision of a discussion in John Locke's Second Treatise of Governmnt, and his discussion of natural rights, Montesquieu argues that the executive, legislative, and judicial functions of government should be assigned to different bodies, so that attempts by one branch of government to infringe on political liberty might be restrained by the other branches. Habeas Corpus is an example of a check that the Judiciary branch has on the Executive branch of government. In a lengthy discussion of the English political system, he tries to show how this might be achieved in order to secure liberty, even in a monarchy. He also observed that liberty cannot be secure where the powers of the three branches of government are not separated, even in a republic.

The second is the appropriate framing of civil and criminal laws so as to ensure personal security.

Montesquieu intended what modern legal scholars might call the rights to "robust procedural due process", including the right to fair trial, the presumption of innocence and the proportionality in the severity of punishment. Pursuant to this requirement to frame civil and criminal laws appropriately to ensure political liberty (i.e., personal security), Montesquieu also argues against slavery and for the freedom of thought, speech, and assembly. Parenthetically, Americans selectively included the freedoms of religion, assembly and petition to firmly protect individual rights of which the Bill of Rights acts as a comprehensive protector of the rights in question. Montesquieu is a strong advocate of the Bill of rights which inherently is part and parcel of the English, French, and American constitutional traditions.

\section{Influence of Climate on Culture and Society}

The third major contribution of De l'esprit des lois was is in the field of political sociology, which Montesquieu invented. Most of the treatise, in fact, concerns how geography and climate interact with particular cultures to produce the "spirit" of a people. This spirit, in turn, influences people toward certain types of political and social institutions, and away from others. Classical scholars and Ibn Khaldun, the Medieval Islamic scholar, tend to affirm that climate is behaviorally deterministic. However, later writers often caricatured Montesquieu's theory by suggesting that he claimed to explain legal variation simply by the distance of a community from the equator. Nevertheless, his approach to politics and from a naturalistic or scientific point of view, proved very influential, directly or indirectly inspiring modern fields of political science, sociology, and anthropology 
particularly in developing countries that with different political cultures.

Demographically Kenyans are very diverse national community of Africans who are composed of 42 ethnicities and a variety of resident citizens whose ancestry can be traced to Asian and European "antiquities". Regardless of its linguistic variety, English and Kiswahili are the official and lingua franca languages respectively. Economically the majority (57\%) are poor. The country has a rich middle class population and a rare upper class to which both Kenyatta and Ruto, his vice president, belong. In this election, a lot of efforts in terms of secure and effective preparation for electronic voting machines, the governance structure of the electoral commission, the tallying and voting processes were made. The six colored ballot paper cards that each voter used to vote for the president, Member of Parliament, senator, governor, women representatives from each county and local councils were put in place. To ensure the security, fairness, and transparency of the election, strategic countrywide deployment of the army, air force, navy, police, and the general service unit (GSU) and the (CID) agents were employed. Also, domestic and international professional journalists, commentators, and activists, leave alone those who were counting and reporting played their roles, did their work well. This electoral machinery was more objective, fair in judgment and credible in resolution than what happened in 2007 post election debacle in Kenya. All in all, unique reactions may vary based on whom you talk to and how those reactions may be influenced by perceptions of class, ethnicity, and race. Even though collectively, the evidence was clear, this time there were no "cockroaches, worms, rats, vermin and jiggers" to kill. Instead, the independence of the domestic and global judiciary was charged with the responsibility for balanced impartiality and accountability of the electoral process. As a result it became a deterrent to potential street fighting. Democracy worked inspite of minor and detectable voting and electronic imperfections.

\section{Comparative analysis of the Two Presidential Personalities}

Table 1

Comparative Analysis of the Two Presidential Personalities

\begin{tabular}{|c|c|}
\hline Uhuru Kenyatta & Raila Odinga \\
\hline $\begin{array}{l}\text { He is the son of Jomo Kenyatta, the kikuyu founding father of the } \\
\text { nation who was a warrior, nationalist authoritarian ruler, brilliant } \\
\text { cultural anthropologist and founder of "African monarchical and } \\
\text { parliamentary democracy" in Kenya. Kenyatta founded KANU } \\
\text { political party that brought independence from Britain to } \\
\text { maintain national security and unity. He progressively influenced } \\
\text { the unilateral dissolution of other opposition parties i.e., (KADU } \\
\text { and KPU) to make Kenya a single-party state. }\end{array}$ & $\begin{array}{l}\text { He is the son of Oginga Odinga the successful Lou businessman } \\
\text { who was also ideologically Russian-based socialist, vice } \\
\text { president of Kenya and founder of Kenya Peoples Union (KPU) } \\
\text { that opposed capitalist based economic development model by } \\
\text { vigorously promoting a Russian/ Soviet and socialist one. }\end{array}$ \\
\hline $\begin{array}{l}\text { Like his father who studied in Britain (West) at the London } \\
\text { School of Economics and Political Science, Uhuru studied at } \\
\text { Amherst in Massachusetts, United states of America. }\end{array}$ & $\begin{array}{l}\text { Unlike his father who had a diploma in mathematics from } \\
\text { Makerere university college, (Uganda), Raila studied } \\
\text { Engineering in East Germany during the soviet socialist era. }\end{array}$ \\
\hline $\begin{array}{l}\text { Uhuru is young ( } 51 \text { years), brilliantly articulate, experienced in } \\
\text { political maneuver, wealthy like the royals and conservatively } \\
\text { cosmopolitan. As a member of the "royal family", he inherited a } \\
\text { lot of wealth some of which is alleged to have been acquired by } \\
\text { force or illegally particularly (the land question) which provoked } \\
\text { the } 2007 \text { post-election violence in which } 1,200-1,500 \text { people } \\
\text { were killed largely in the Rift valley and for which Uhuru and } \\
\text { Ruto have been inducted by the International Criminal } \\
\text { Court(ICC) at the Hague. }\end{array}$ & $\begin{array}{l}\text { Raila is about ( } 70 \text { years) old, more politically experienced than } \\
\text { his protagonist, eloquent in both English and Kiswahili, } \\
\text { apparently more popular than both Mwai Kibaki and Uhuru } \\
\text { Kenyatta, given credit for the creation of the new federal } \\
\text { constitution. His father wrote "Not yet Uhuru" for which his } \\
\text { party was banned and Oginga Odinga indefinitely detained for } \\
\text { Kenya to rationalize a single party state in the country. Similarly, } \\
\text { Raila was brilliantly appeased with a temporary Prime } \\
\text { Ministership in order to avert the } 2007 \text { post-election crisis of } \\
\text { violence that threatened potential disintegration of the nation. }\end{array}$ \\
\hline
\end{tabular}


In the final analysis, Kenyatta legitimately won the presidency in political, constitutional, and metaphysical terms. Now, he should initiate a national, ideological, and psychological structure for reconciliation. The success of the reconciliatory structure will be influenced by its complexity, trust, objectivity, and transparency.

A truth and reconciliation body system should be set up to bring peace. An East African court or supranational court should be set up to deal with ABCD's of the judicial conflicts before they are "transnationally and illegitimately" reported to the ICC at Hague in Holland for culturally integrative and homogenization interests that are epistemologically hegemonic, culturally irrelevant, and nationally exotic. In doing what they do, the authority, sovereignty, and relevance of an African state and its governance mechanisms are denationalized, deregionalized, deterritorialized, and unbundled. It should be remembered that each civilization's legal codes, theories and ideas are rooted in its historical, cultural, and judicial jurisprudence that radically differ from that of the other civilizations that Tonybee talks about. If Rome statute is European, are Nairobi or Kampala statutes European too? Globalization tends to homogenize and hegemonize hyperglobally. In doing so, it tends to disempower the identity, authority, and sovereignty of other nations at the periphery. However, as evidence has shown, it is not without certain maximal usefullness either.

\section{Globalization}

The term globalization covers a wide range of distinct political, economic, technological, judicial, and cultural trends. The trends are embedded in the free market whose ideology possesses ruling power. The pursuit of classical liberal or "free market" policies in the world economy is known as economic liberalization. The three major notions that clarify economic liberalization include but are not limited to: the growing dominance of western forms of political, economic, and cultural life that constitute westernization; the proliferation of new information technologies (the internet revolution); and the notion that humanity stands at the threshold of realizing one single and unified world community in which major sources of social conflict have vanished (global integration) or hyperglobalization. While liberalization denotes the practice of democracy, free and fair elections, rule of law and human rights; globalization, on the other hand, means that multinational corporations and their governments have acquired power through the IMF, the World Bank, WTO, and the EU. The ICC is its legal arm for juridico-political governance and global dominion. In this arena, civilizations have been enhanced through competition, denationalization, and renationalization of third world nation-states that have illegitimately lost their authority and sovereignty for managing their affairs.

In the light of this definition, globalization is characterized by five major trends in terms of virtual reality, deterritorialization (absence of boundaries), interconnectedness (interdependence), speed or velocity, and long-term (strategic) and multi-pronged processes for solving problems. The meanings and trends of globalization are rationalized in the context of international political economy. The traditional schools of international political economy (IPE) that reinforce continuous human and interactive contacts are mercantilism, liberalism and Marxism. Though these schools are necessary for enabling governments to make foreign economic policy outcomes, they do not effectively explain how governments should behave. This challenge is handled within the province of international relations theory through which liberal, constructivist, and realist schools of international relations are employed to solve problems (Kegley, 2002). In reality, contemporary globalization is largely economic and cultural: Political globalization (i.e., having one world government), in its 
pure form is impractical, undesirable and at worst, a form of global tyranny (Yunker, 2007). During the last four centuries, according to Dani Rodrik (2011) that shows Western hubris of Harvard, globalization has been inimically and paradoxically applied throughout its gold standard period that was regulated under (GATT) Bretton Woods Regime, (IMF, World Bank), the Washington Consensus and lately (WTO) World Trade Organization. For these four centuries, globalization has both radically succeeded and dramatically and drastically failed periodically largely due to society's simultaneous and triadic pursuit of democracy, national self-determination and economic globalization. Failure is experienced because of the conflictual clash between the social arrangements of democracies and the international demands of globalization. Since this relationship is chronically more a symmetrical than balanced, globalization has historically continued to suffer not only in the areas of instability in trade, finance, and markets, but also in relation to the lack of "hyperglobalization" orchestrated by the absence of profound economic integration and free trade. Worst of all, due to Bagwatian unrestricted capital mobility, globalization has caused rampart deindustrialization, economic inequality, and the weakening and collapse of standards of living in developed countries. It has also caused unemployment in developing economies. Globalization has consistently been the cause of underdevelopment in terms of the brain drain, underdevelopment caused by lack of subsidies, exploitation of minerals, gas, erosion of state power, and corruption of political governance. It is also responsible for unemployment and underemployment whose side effects include but are not limited to offshoring and outsourcing nexus of which Goldenburg and Anglo-leasing are classic.

\section{Interpretive and Comparative Conclusion and Discussion: Legacies}

In this election,the historical ascendance of pro-Western and capitalist socio-economic and political class had politically delegitimized and marginalized its historically entrenched marxist rival. Even though, this decimation of the traditional opposition did not happen in a vacuum. The perception that the opposition was more popular, vocal and less corrupt did not appear to deliver. Three points were clear:

(1) The historic socioeconomic dominance of the conservative and Bantu-Nilohamite based tribal alliance (Jubilee) has became the fulcrum whose checks and balances have become the epicenter for strategically measuring the nation's political temperature that determines its cyclical political behavior including electoral winning and perpetual alliance dominance in Kenya's political arena.

(2) The mighty and reknown intellectual resources which the Luo community possesses are too largely "buried" in universities and the bureaucracy to effectively unite and mobilize the economically marginalized majority of the population for assertively changing the ethnic-based and pluralistic political equation in favor of the (CORD) coalition.

(3) The historical and political rivalry between the leaders of the two most powerful ethnic groups may be viewed as a conflict over the nation which espouses materialistic vis-avis Marxist and communitarian values. For now, as in the past, the former are ascendant. History has enigmatically repeated itself in the sea of political tranquility vindicated by the new constitution.

The internal, external and cyclical interplay of historical and global forces are so entreched and understood by the Kenyan system of the elite ruling class who cooperate with the global and international systems for interdependent mutual advantage. A lesser globally interconnected segment of tribal or national constituency will 
hardly weigh the balance which the epicenter rationally and historically tends to equanimate for purposes of the winner's self-preservation. At the juncture of relative national confusion, circumstances control men, men do not control circumstances (Herodotus). That is what happened to both the two Odingas and the two Kenyattas and their successive and competitive political regimes in the last 50 years since independence.

In this apparent confusion, the question of land that the colonial settlers owned and that was never returned to the original tribal/regional owners, but was instead either sold to single owners in acreages or grabbed graftly by a few powerful individuals including the Kenyattas family, has continued to be the bone of contention between the haves and the have-nots. For the last 50 years, and more so since 1992, every quinquennial presidential cycle, land issues have been the genesis for post-election violence particularly in the Rift Valley. This year was different because the new constitution and the ICC acted as deterrents to the genesis of potential political problems.

Did Uhuru win the 2013 presidential elections? Since the fact that the new constitutional framework and the ICC have became the cornerstones for cautious optimism, judicial jurisprudence, and legal guardianship for justice, fairness, and democracy, Uhuru Kenyatta's victory has historically and legitimately been institutionalized. The CORD movement appealed the presidential results which Kenyatta used to declare victory in an election whose electronic machine system was "paralyzed", causing what might be interpreted as an element of voter suppression. Historically, electoral rigging is a form of voter suppression which tends to deny the winner his or her victory in an election. In the light of this apparent confusion, Raila Odinga appealed Kenyatta's claim to victory. If the Kenyan courts had nullified the election for malpractice, electronic voter suppression and other forms of activist and intentional rigging, a runoff would have been declared and the entire electorate would have been taken back to square one. For now, the second Republic has ratified Kenyatta's victory. Based on circumstances, either of the two men could have won this election. If Raila Odinga had won the appeal for the runoff election, his victory would have delegitimized the Bantu-NiloHamitic Political mythology and the ideologically induced and rustic political mentality of Kikuyu political entitlement that is rooted in the myth of Mau-Mau and its nationalist struggle for political independence from Britain. On the other hand, Odinga would have been viewed as a great leader whose political strategy, personality, and vision could have not only enabled him to introduce constructive and institutionalized reforms, but such a form of deliberative political thinking would have portrayed him as a charismatic champion for change and meritocratic politicization of the nation. For both candidates, neither prospective (what they will do) nor retrospective (what they did as presidents) issues were relevant. The election was largely fought on personalities rather than issues. In this respect, Kenya's electorate and tribalistic political culture needs to graduate from infancy to maturity by using issues as opposed to personalities in order to make electoral politics more scientific and objective in measurement. Above all, and behind the scenes, the Kenyatta-Ruto alliance, which relies on political patronage, rent-seeking behavior and neo-patrimonialism may have conclusively proved to be more competitive than its politically a stute but economically, globally, and strategically inefficient counterpart.

The Kenyatta /Oginga contest did not happen in a political vacum. This was a contest of the Titans whose rhythim was informed by the ethos of pre-independence, post-independence and African/Kenyan political culture, the management styles and political regimes of the three first presidents (Jomo Kenyatta, Daniel Arap-Moi, and Mwai Kibaki). Jomo Kenyatta, the greatest of them all, was an intellectual scholar who wrote four books, an international Pan-Africanist, a natural leader, anthiropologist, moderate politician, and founder of KANU which 
brought independence to Kenya in 1963. He consolidated power by either detaining his opponents or creating a climate for their elimination. He appealed to ethnic rather than national loyalties, a practice of his successors have continued to follow for political competition without ceasing. He brilliantly and gradually Africanized the bureaucracy in post independence Kenya, creating institutions that enabled the country to relatively become prosperous and capitalistic. He laid a sound and pro-Western and strong anti-Communist economic and foreign policy foundation for Kenya.

Jomo Kenyatta was not a flaw free man. Although his administration supervised Kenya's admission into the $\mathrm{UN}$, this founding father failed to organize the nation to be a multi-ethnic state rather than a defacto confederation of rival tribes. His authoritarianism was characteristic of "patronage, favouritism, tribalism... and nepotism". ${ }^{1}$ He dissolved opposition parties and amended the constitution to seifishly consololidate his powers whose influence was marked by corruption and bureaucratic inefficiency. Wealth accumulation by public officials, land grabbing by similar officials and the Kenyatta family was common practice and its effects were highly pronounced in 2007 post-election violence. His policies encouraged inequality and abject poverty in peripheral areas. Because he assumed power at a very advanced age that contributed to his frequent illiness, evidence shows that much of the corruption that happened was done by his cronies without his knowledge.

President Moi succeded Kenyatta in 1978 and followed Kenyatta's footsteps (Nyayo). Though both were dictatorial, anti-Communist, and more antiquated in social values, Kibaki was more enlightened in social graces, bureaucratic leadership, and global vision. Kenyatta was an African imperialist, Moi was a despot while Kibaki was an intelligent and competent technocrat. Moi practiced primitive populism like many third world leaders. Kibaki had no cult mentality or personality like his predecessors. He was consistently technocratic, withdrown, a loof and yet, he delegated his authority with a sense of dysfunctionalism which in the end served him well. Of the three, Moi encouraged kleptocracy more than democracy. Kenyatta and Moi imprisoned and tortured and sometimes eliminated their their worst opponents. Kibaki debated with his opponents, was more democratic and tolerant than the two men of "antiquity". Kenyatta ruled for three terms, Moi for five and Kibaki for two. The first and the third built strong economies and constitutions, the second abused them and took the country back to antiquity partly because he had no university education and his power base was thinner compared to that of the other two. Most of the time he reacted to issues and events without digesting them, but only to reverse his decisions latter after the damage had been done. This kind of environment produced a political culture which informed Uhuru Kenyatta and Raila Odinga in their competion for the highest office in the land. From this analysis, it is obviously self explanatory for what you could expect out of it. Although political activists such as Ngugi Wathiongo and critics such as Martin Shikuku, the poor man's watchmam, attempted to articulate reform by writing and speaking against corruption in favor of a just socio-economic order, their criticism was either ignored or punished with long detantions or torture or sudden and spasmodic eliminations.

\section{References}

Abdelal, R., \& Meunier, S. (2006). La Regle du Jeu: France and the paradox of managed globalization. (Paper presented at the Annual Meeting of the American Political Science Association, August 30th-September 3rd).

\footnotetext{
${ }^{1}$ See https://en.wikipedia.org/wiki/jomo_Kenyatta.
} 
Bok, H. (1989). Montesquieu: Spirit of the laws. In M. C. Anne, C. M. Basia, and S. S. Harold (Eds.), Cambridge texts in the history of political thought. Cambridge: Cambridge University Press. ISBN 0-521-36974-6 (10). ISBN 978-0-521-36974-9 (13).

Bok, H. (July 18, 2003). Baron de Montesquieu, Charles-Louis de Secondat. Retrieved from http://plato.stanford.edu/entries/montesquieu/

Brzezinski, Z. (1998). The grand failure: The British and death of communism in the twentieth century. New York: Charles Scribner's Sons.

de Secondat, Charles, Baron de Montesquieu. (1748). The spirit of the laws (Vols. 1-2). Retrieved from http://www.constitution.org/cm/sol-02.htm

de Secondat, Charles, Baron de Montesquieu. (1793). The spirit of laws: Volume 1. Retrieved from http://librivox.org/the-spirit-of-laws-volume-1-by-montesquieu/

de Secondat, Charles, Baron de Montesquieu. (1793). The spirit of laws: Volume 1. Retrieved from http://books.google.com/books?id=5zZJAAAAMAAJ

de Secondat, Charles, Baron de Montesquieu. (1793). The spirit of laws: Volume 2. Retrieved from http://books.google.com/books?id=5zZJAAAAMAAJ

de Secondat, Charles, Baron de Montesquieu. (n.d.). The spirit of laws. Retrieved from http://www.archive.org/details/spiritoflaws01montuoft The Spirit of Laws

Etzioni, A. (2004). From empire to controversy: A new approach to internationala relations. Palgrave Macmillan.

Faith, K., \& Nima, E. (2013). Vote counting begins after largely peaceful election in Kenya. CNN. Retrieved from http://edition.cnn.com/2013/03/04/world/africa/kenya-elections/index.html

Fukuyama, F. (2004). State building: Governance and world order in the twenty first century. Ithaca: Cornell University Press.

Fukuyama, F. (2006). America at the cross-roads: Democracy, power and the neoconservative legacy. New Haven, CT: Yale University Press.

Gore, A. (2013). The future: Six drivers of global change. New York: Random House.

Huntington, S. P. (2006). Globalization and state power: A Reader. New York: Pearson Longman.

Katz, W. (2011). Globalization and democracy. Globality Studies Journal, 1-5.

Kegley, C. W. (2002). World politics: Trends and transformation. (Unpublished Manuscript).

Museueni, Y. (2013). 10 reasons why most African countries are least developed. Retrieved from http://www.africanexecutive.com/modules/magazine/articles.p hp?article=71850 \&magazine

Parsons, T. (2010). The rule of empires: Those who built them, those who endured them, and why they always fall. New York: Oxford University Press.

Rodrik, D. (2011). The globalization paradox: Democracy and the future of the world economy. New York: W.W. Norton.

Sagini, M. M. (2008). The Africian-bureaucracy and the challenges of managerial leadership. KESSA Conference Abstracts.

Sagini, M. M. (2013). Globalization: The paradox of organizational behavior: Terrorism, foreign policy and governance. Lanham: Rowman and Littlefield. Publisher Inc.

The spirit of the laws. (n.d.). Retrieved from http://en.wikipedia.org/wiki/TheSpiritoftheLaws

Toybee, J. A. (1889). Biography. Retrieved from http://en.wikipedia.org/wiki/ArnoldJ._Toynbee

Wittkopf, E. R., \& McCormick, J. M. (Eds.) (1999). The domestic sources of American foreign policy: Insights and evidence. Lanham, MD: Rowman and LittleField Publishes, Inc.

Yunker, J. A. (2007). Political globalization: A new vision for federal world government. Lanham: University Press of America. 